\title{
ECONOMIC ANALYSIS OF SMALL HOLDER RICE PRODUCTION SYSTEMS IN EBONYI STATE SOUTH EAST, NIGERIA
}

\author{
Nwaobiala C.U., Researcher \\ Michael Okpara University of Agriculture, Umudike, Nigeria \\ E-mail: cunwaobiala@gmail.com
}

Adesope O.M., Researcher

University of Port Harcourt, Rivers State, Nigeria

E-mail: omadesope@yahoo.co.uk

\begin{abstract}
Economic analysis of Upland and Swamp rice production in Ebonyi State, South east Nigeria was studied and analyzed in 2011 farming season. Purposive and multistage random sampling technique was used to select agricultural blocks, circles and rice farmers. The sample size was 240 rice farmers (120 Agricultural Development Programme (ADP) Upland rice contact farmers and 120 Agricultural Development Programme (ADP) Swamp contact rice farmers). Data for the analysis were collected from a structured questionnaire. The result indicates that mean ages of upland rice farmers was 37.3 years while swamp rice farmers had 39.2 years. The mean farming experience for both farmers were 8.5 years (upland rice farmers) and 8.8 years (swamp rice farmers) with farm sizes of 1.2 and 1.1 hectares for upland rice farmers and swamp rice farmers respectively. Upland rice farmers had an annual farm income of 189,410.00 NGN (1,222USD) as against 201,166.00 NGN (1,297.85USD) for Swamp rice farmers. The multiple regression (Cobb Douglas) estimates of the determinants of output of upland rice showed that coefficients age, farming experience, farm size, variable inputs and farm income were positively signed at given levels of probability while capital inputs was negative. The Cobb Douglas regression estimates of the determinants of output of Swamp rice showed that the coefficients of education, labour cost, farm size, variable inputs and farm income were positively signed and significant at given levels of probability as well as capital inputs which was negative. The result indicates that net profit from Upland rice cultivation was 92,800.00 NGN (598.71USD) with a Benefit Cost Ratio of N1.55 (1.56USD). The net profit from Swamp rice cultivation was 132,090.00 NGN (852.19USD) and a Benefit Cost Ratio of 1.75 NGN (1.75USD). Access to credit to rice farmers, subsidy on farm inputs, dissemination of improved rice technologies by extension agents and formation of farmer groups were advocated for increased rice production.
\end{abstract}

\section{KEY WORDS}

Economic; Analysis; Upland rice; Swamp rice; ADP farmers.

The Nigerian rice sector has a lot of potentials for increased rice productivity as the country is blessed with abundant rice growing environment. However, WARDA (2004) noted that rice policy in Nigeria is characterized by inconsistency shifting, between open and protectionist trade policy and such changes hinder the ability of stakeholders to develop long term strategies for the growth of the sector. FAO (2004) identified rice as a very important primary food source and this is drawn from the understanding that rice-based systems are essential for food security, poverty alleviation and improved livelihoods by enhancing the socio- economic profile / status of the farmer. Rice is grown in paddies or on upland fields depending on the requirements of the particular variety, there is also limited mangrove cultivation. Upland rice production is practiced on different ecologies by majority of farmers due to it less tedious operation. Upland contributes substantially less the total rice output in relation to its share in total area, but still accounts for an important means of rice production (WARDA 2003 et al., and Oyewole et al., 2010). In Nigeria, out of 4.6 million hectares available for rice production, only 1.7 million hectares are put to rice cultivation, despite that its production is labour intensive and labour represents major production costs (Nwachukwu 
et al., 2008). Rice is produced in the middle belt, south east and some far northern states of Nigeria (Audu, 2008).

Rice production in Nigeria between 2001 and 2003 was estimated at 2.03 million mega grams while consumption was 3.96 million grams. The balance of 1.90 million mega grams was obtained by importation (FAO, 2004). Nigeria is the largest producer of rice in West Africa producing over $40 \%$ of the regions total production (Singh et al., 1997 and FAOSTAT, 2007). In the past 30 years, production has increased six folds with Nigeria producing 3.3 and 3.6 million tons of paddy rice in 2000 and 2005 respectively (FAOSTAT, 2004 and 2007). Africa accounts for only about $2 \%$ of the worlds output of rice. Current production stands at 2.8 million tons with a deficit of 1.6 million tons excluding the quantity smuggled through the porous borders (USAID, 2008). The successive programmes launched to increase rice production have not been able to reduce the resulting rice deficit. The imposition of a ban on rice import from 1985 to 1995 and ensuring increase in the relative price against other major staples boosted rice production mainly through area increase. Past policies did not help local rice producers to secure significant market share and imports have increased since the lifting of the ban and successive increase in the import tariff from $50 \%$ to $100 \%$. Imported rice represents more than $20 \%$ of agricultural imports and half of total rice consumption (WARDA, 2003). In spite of the relative increase in the price of rice per capita, consumption has maintained the upward trend showing that rice has become a structural component of Nigeria diet with a low price elasticity of demand (WARDA, 2003). Massive importation of food especially rice in recent years is an indicator of poor state of nations agricultural and technologies development, occasioned by poor productive propensity of the farmers. Increase in agricultural import is a disincentive to local farmers to produce and may cause reduction in farming population which can subsequently lead to a reduction in agricultural output. The production process involving costs and the magnitude of costs influence the magnitude of profit (Anuebunwa, 2004 and 2007). Many studies on rice production were geared towards maximizing profit, ignoring socio- economic factors of the farmers which influence and contribute to rice production. Problems of rice production are identified as relatively high production costs, relatively poor producer prices and marketing systems, this results to low returns and subsequently decline in rice production (FAO, 2008; Ugwugwu, 2008). In view of the above, this study tends to analyze the economics of smallholder rice production systems in Ebonyi State, Nigeria. The specific objectives of this paper are to:

a. describe selected socio-economic characteristics of ADP Upland and Swamp rice farmers in the study area.

b. determine the influence of socio-economic variables on the output of ADP Upland and Swamp rice farmers in the study area.

c. estimate the cost and returns of Upland and Swamp rice farming in the study area. Hypotheses:

$\mathrm{Ho}_{1}$ : Socio-economic characteristics of rice farmers do not have significant relationship on the output of ADP Upland and Swamp rice Contact farmers.

$\mathrm{Ho}_{2}$ : Upland and Swamp rice farming are not profitable.

\section{METHODOLOGY}

The study was conducted in Ebonyi State South east Nigeria, which is one of the major rice producing areas in Nigeria. The State has 13 Local Government Areas and 3 agricultural zones namely Ebonyi North (Izzi, Abakaliki, Ohaukwu and Ebonyi Blocks): Ebonyi Central (Ishielu, Ikwo, Ezza South and Ezza North Blocks) and Ebonyi South (Afikpo, Afikpo South, Onicha and Ohazara Blocks). The State has a land mass of approximately $5,932 \mathrm{~km}^{2}$ and lies within latitudes $4^{1} \mathrm{~N}$ and $14^{1} \mathrm{~N}$ of the Equator and longitudes $3^{\circ} \mathrm{E}$ and $15^{\circ} \mathrm{E}$ of Greenwich meridian. The State has a population of about 2.3 million people (NPC, 2006). The State has an average rainfall of $1200 \mathrm{~mm}-2000 \mathrm{~mm}$ with temperature ranging from $33^{\circ} \mathrm{C}$ in the dry season and about $16^{\circ} \mathrm{C}$ to $18^{\circ} \mathrm{C}$ in the rainy season (EBADEP, Annual Record, 2005). Rice farming is predominantly practised by farmers in the State. 
Purposive and multistage sampling techniques were used in the selection of agricultural blocks, circles and rice farmers. Purposively, Ebonyi State was chosen because it is among the major rice growing areas in Nigeria. The three agricultural zones namely Ebonyi North, Ebonyi Central and Ebonyi South were used for the study. First, 2 blocks were randomly selected from the three agricultural zones to give a total of 6 blocks (Ebonyi North - Izzi and Abakaliki Blocks : Ebonyi Central - Ikwo and Ezza South Blocks and Ebonyi South - Onicha and Ohazara Blocks). Also, 2 circles each were randomly selected from the selected blocks which gave a total of 12 circles. Furthermore, 10 ADP Upland rice Contact farmers were randomly selected from the selected circles to give a total of 120 ADP Upland Contact farmers. Finally, 120 ADP Swamp rice Contact farmers were selected from the areas where the Upland rice farmers were chosen to give a grand sample size of 240 ADP rice Contact farmers. Descriptive statistics such as frequency distribution, mean counts and percentages were used to realize objective $\mathrm{i}$ while multiple regression analysis achieved objectives ii and iii.

Theoretical Framework. The multiple regression studies involve the nature of relationship between a dependent variable and two or more explanatory variables. The techniques produce estimates of the standard error of multiple regression and coefficients of multiple determinants. In implicit form, the statement that a particular variable of interest (Y) is associated with a set of the other variables $\left(X_{I}\right)$ is given as:

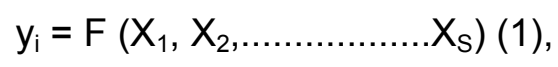

where $y_{i}$ is the dependent variable, and $X_{1} \ldots \ldots \ldots . . . . X_{2}$ is a set of a $k$ variables.

The coefficients of multiple determination measures the relative amount of variation in the dependent variable $\left(Y_{i}\right)$ explained by the regression relationship between $Y$ and the explanatory variables $\left(\mathrm{X}_{1}\right)$. The F- Statistics tests the significance of the coefficients of the explanatory variables as a group. It tests the null hypothesis of no evidence of significant statistical regression relationship between $Y_{i}$ and the $x_{i} s$ as against the alternative hypothesis of evidence of significant statistical relationship. The critical $\mathrm{F}$ - value has an $\mathrm{n}$ and $n-k-1$ degrees of freedom, where $n$ is the number of respondents and $k$ is the number of explanatory variables. The standard error of regression coefficients is the measure of error about the regression coefficients. The nature of the relationship between an outcome variable $\left(Y_{i}\right)$ and a set of explanatory variables $\left(X_{1}\right)$ can be modelled using different functional forms. The four commonly used algebraic (functional) forms are: linear, semi- log, exponential and Cobb Douglas.

The four functional multiple regression models were employed to select the one that has provided the best fit. The choice of best functional form was based on the magnitude of the $R^{2}$ value, number of significant variables, size and sign of regression coefficients as they conform to a priori expectation. The four functional forms were specified implicitly as follows;

(i) Linear Function

(ii) Semi-log function

$$
Y=b_{0}+b_{1} X_{1}+b_{2} X_{2}+b_{3} X_{3}+b_{4} X_{4}+b_{5} X_{5}+b_{6} X_{6}+b_{7} X_{7}+b_{8} X_{8}+b_{9} X_{9}+e i
$$$$
Y=L_{n} b_{0}+b_{1} L_{n} X_{1}+b_{2} L_{n} X_{2}+b_{3} L_{n} X_{3}+b_{4} L_{n} X_{4}+b_{5} L_{n} X_{5}+b_{6} L_{0} X_{6}+b_{7} L_{0} X_{7}+b_{8} L_{0} X_{8}+b_{9} L_{0} X_{9}+e i
$$

(iii) Exponential function

$$
\operatorname{LnY}=b_{0}+b_{1} X_{1}+b_{2} X_{2}+b_{3} X_{3}+b_{4} X_{4}+b_{5} X_{5}+b_{6} X_{6}+b_{7} X_{7}+b_{8} X_{8}+b_{9} X_{9}+e i
$$

(iv) Cobb Douglas Function

$$
L n Y=L_{n} b_{0}+b_{1} L_{n} X_{1}+b_{2} L_{n} X_{2}+b_{3} L_{n} X_{3}+b_{4} L_{n} X_{4}+b_{5} L_{n} X_{5}+b_{6} L_{n} X_{6}+b_{7} L_{n} X_{7}+b_{8} L_{n} X_{8}+b_{9} L_{n} X_{9}+
$$
ei

$\mathrm{Y}=$ Output of Rice in $\mathrm{Kg} /$ tons; $\mathrm{X}_{1}=$ Age in years;

$\mathrm{X}_{2}=$ Household Size; $\mathrm{X}_{3}=$ Education

$\mathrm{X}_{4}=$ Farming Experience in Years; $\mathrm{X}_{5}=$ Farm Size in Hectares

$\mathrm{X}_{6}=$ Labour Cost in Naira; $X_{7}=$ Variable Inputs in $\mathrm{Kg}$

$X_{8}=$ Capital Inputs in NGN/USD; $X_{9}=$ Farm Income in NGN/USD

ei $=$ error term 
The budgetary technique was used to determine the profitability of rice production systems in the study area. Gross margin analysis is one of the budgetary techniques and it basically measures the difference between total returns and total variable costs. Gross margin of rice farming is the total value of production (Total revenue) and the variable costs of production. The total revenue refers to the gross income accruing from rice farms as a result of the sales of processed rice. This is obtained by multiplying the unit price of average processed rice by the quantity sold. The variable costs are those costs that vary with the total level of output. The addition of total variable costs and total fixed costs gives the overall costs incurred in production. However, for the purpose of arriving at fixed costs of the rice farms for a given year, the straight line depreciation method was used taken into consideration the expected life span of the different fixed cost items. Using the straight line method, the annual depreciation expenses are calculated on the fixed costs, which are then used to get the net farm profit. The benefit cost ratio which expresses the return in investment a farmer gets in producing a commodity is derived by dividing total revenue by total costs used in production. (2010):

The Gross margin analysis adopted in this paper is in accordance with Nwaobiala,

$$
G M=\Sigma p i(Q i-\Sigma p j X i) \ldots(i),
$$

where $\mathrm{GM}=$ Gross Margin; $\mathrm{Pi}=$ Unit price of output; $\mathrm{Qi}=$ Quantity of each output; $\mathrm{Pj}=$ Unit of each input; $\mathrm{Xi}=$ Quantity of each input.

$$
\begin{gathered}
\mathrm{NR}=\mathrm{GM}-\mathrm{TFC} \ldots \text { (ii) } \\
\mathrm{BCR}=\mathrm{TR} / \mathrm{TC},
\end{gathered}
$$

where NR $=$ Net Revenue; TFC $=$ Total fixed costs derived by depreciation of fixed costs; $\mathrm{BCR}=$ Benefit Cost Ratio; TR = Total Revenue; TC = Total Costs.

\section{RESULTS AND DISCUSSION}

Socio-economic Characteristics of ADP Contact Rice Farmers in Ebonyi State, Nigeria. The result indicates that the mean age of ADP Upland rice contact farmers was 37.70 years while the Swamp rice contact farmers was 39.20 years. Also 5.1 and 5.2 were household sizes of ADP Upland and Swamp rice contact farmers respectively. The ADP Upland rice and Swamp rice contact farmers had 8.5 and 8.8 years of farming experiences respectively and mean farm sizes of 1.2 hectares (ADP Upland rice contact farmers) and 1.1 hectares (ADP Swamp rice contact farmers). The annual farm income of ADP Upland rice contact farmers was $189,410.00$ NGN $(1,222$ USD) while ADP Swamp rice Contact farmers had $201,166.00$ NGN (1,297.85USD).

Socio economic Factors Influencing the Output of Upland Rice in Ebonyi State, Nigeria. Our study shows the Ordinary Least Square (OLS) multiple regression estimates of the determinants of Upland rice Output in Ebonyi State, Nigeria. The Cobb Douglas functional form was chosen as lead equation based on the high $R^{2}$ value, sizes and numbers of significant variables and agreement with a priori expectation. The $R^{2}$ value of 0.7412 indicates $74.12 \%$ variability in output of Upland rice was explained by the independent variables. The F-value (9.874) was highly significant indicating a regression of good fit.

The coefficient of age (0.00471) was positively signed and significant at $5 \%$ level of probability. This implies that as age increases the probability of the farmer to produce more quantities of upland rice increases. This is against a priori expectation. Probably because accumulated knowledge and experience of farming systems a farmer had acquired pays off over a long period of time, while costs occur in earlier stages (Bonabana - Wabbi, 2002).

The coefficient of farming experience $(0.3714)$ was positively signed and significant at $10 \%$ level of probability. This is in agreement with a priori expectation. The positive sign implies that an increase in farming experience will lead to a corresponding increase in the output of upland rice. This may be that farmers had acquired encouraging return from upland rice cultivation and thus will continue with it anticipating continued benefits. This result is in 
consonance with the findings of Nwaobiala, (2010) where there was a relationship between farming experience and output of rice farmers in Ebonyi State.

The coefficient of farm size $(0.00129)$ which was positive was highly significant at $1 \%$ level of probability. This implies that an increase in farm size will result to an increase in the output of Upland rice in the study area. This is in agreement with a priori expectation. This result is in conformity with the findings of Ezeh, (2006) as he found a positive influence of farm size on the output of Upland rice in Abia State, Nigeria.

The coefficient of variable inputs (11970.41) was positively signed and significant at $5 \%$ level of probability, implying that an increase in quantities of variable inputs used in the production of Upland rice will increase output of Upland rice. This is in agreement with a priori expectation. This result is in consonance with the findings of Onyenweaku et al., (2010) as they found a positive relationship between rice seeds and quantities of fertilizer used in rice production in Abia State, Nigeria.

The coefficient of capital inputs (- 0.00524) which was depreciated was negatively related to output of Upland rice. This implies that any increase in the cost of capital inputs will bring about increase in the output of Upland rice. This is in agreement with a priori expectation. Mbanasor and Obioha (2003) asserted that capital inputs used in any farming operation have a resultant effect on the output of the enterprise.

The coefficient of farm income (14.35774) was positively signed and highly significant at $1 \%$ level of probability. This implies that any increase in farm income will lead to an increase in output of Upland rice farmers. The result is in agreement with the findings of Nwaobiala et al., (2009) where they found a positive relationship between farm income and output of Agip- Green River Project crop farmers in Rivers State, Nigeria.

Socio economic Factors Influencing the Output of Swamp Rice in Ebonyi State, Nigeria. Our study shows the Ordinary Least Square (OLS) multiple regression estimates of the determinants of Swamp rice Output in Ebonyi State, Nigeria. The Cobb Douglas functional form was chosen as lead equation based on the high $R^{2}$ value, sizes and numbers of significant variables and agreement with a priori expectation. The $\mathrm{R}^{2}$ value of 0.8214 indicates $82.14 \%$ variability in output of Swamp rice were explained by the independent variables. The F-value (10.241) was highly significant indicating a regression of good fit.

The coefficient of education (0.00941) was positively signed and significant at $10 \%$ level of probability. This implies that increased level of education will lead to increase in the output of Swamp rice in the study area. This is in agreement with a priori expectation. Generally education is thought to create a favourable mental attitude for acceptance of new practices which in return leads to increased output (Ezeh and Nwachukwu, 2010).

The coefficient of labour cost $(0.06157)$ was positively signed and significant at $5.0 \%$ level of probability. This implies that an increase in the cost of labour will lead to a corresponding increase in the output of Swamp rice in the study area. This is in disagreement with a priori expectation. Since Swamp rice cultivation requires tedious and labour intensive operations, skilled labour needed for farming operation may be too costly to hire. This result is in conformity with the findings of Nwaobiala, (2013) who found a positive relationship between cost of labour used by IFAD farmers and their farm output in Abia and Cross River States, Nigeria. Umebali, (2007) who reported that labour is expensive and has driven farmers to use both family and hired labour. The high cost of labour in small holder agriculture is due to ageing of farmers and migration of youths from rural to urban areas.

The coefficient of farm size $(0.60387)$ which was positive was highly significant at $1 \%$ level of probability. This implies that an increase in farm size will result to an increase in the output of Swamp rice in the study area. This is in agreement with a priori expectation. Farm size is therefore a strong determinant of Swamp rice output in Ebonyi State.

The coefficient of variable inputs $(0.12473)$ was positively signed and highly significant at $1.0 \%$ level of probability, implying that an increase in quantities of variable inputs used in the production of Swamp rice will increase output of Swamp rice. This is in agreement with a priori expectation. This indicates that variable inputs are strong determinant of the output of Swamp rice in the study area. 
The coefficient of capital inputs $(-0.005789)$ which was depreciated was negatively related to output of Swamp rice. This implies that any increase in the cost of capital inputs will bring about increase in the output of Upland rice. This is in agreement with a priori expectation. Therefore depreciation of capital inputs is a strong determinant of Swamp rice output in the study area.

The coefficient of farm income $(0.05945)$ was positively signed and highly significant at $1.0 \%$ level of probability. This implies that any increase in farm income will lead to an increase in output of Swamp rice farmers. This is in agreement with a priori expectation. Therefore farm income is a strong determinant of Swamp rice output in the study area.

Profitability Analysis of Upland Rice Farming in Ebonyi State, Nigeria. Our study shows the gross margin analysis of upland rice farmers in the study area. This posted a total revenue of two hundred and fifty nine thousand naira (\$259.000.00) (16.71 USD). The average annual or seasonal cost incurred in rice production in Ebonyi state was on hundred and thirty thousand six hundred naira $(\$ 130,600)$ (842.58 USD). The Gross Margin was one hundred and twenty eight thousand four hundred naira ( $\$ 128,400.00)$ (828.38 USD) . The total fixed cost per hectare is Thirty five thousand six hundred naira $(\$ 35,600.00)(229.67$ USD). Thus, each farmer is left with average net profit of Ninety two thousand eight hundred naira only $(\$ 92,800.00)$ (598.71 USD). The Benefit Cost Ratio of Upland rice farming was $1: 55$, which means that every $\mathrm{NI}(\$ 1)$ a farmer used in the cultivation of Upland rice he realizes $\mathrm{N} 1.55 \mathrm{k}$.

Profitability Analysis of Swamp Rice Farming in Ebonyi State, Nigeria. Our study shows the gross margin analysis of Swamp rice farmers in the study area. This posted a total revenue of three hundred and six thousand six hundred and thirty naira $(\$ 306,630.00)$ (1978.26 USD). The average annual or seasonal cost incurred in rice production in Ebonyi State was one hundred and thirty nine thousand naira ( $\$ 139,000.00)$ (896.77 USD). The Gross Margin was one hundred and sixty seven thousand six hundred and thirty naira ( $\$ 167,630.00$ ) (1081.48 USD). The total fixed cost per hectare is thirty six thousand five hundred and forty naira ( $\$ 36,540.00)$ (235.74 USD). Thus, each farmer is left with an average net profit of one hundred and thirty two thousand and ninety naira only (\$132,090.00) (852.19 USD). The Benefit Cost Ratio of Upland rice farming was 1:75, which implies that, for every $\mathrm{NI}(\$ 1)$ a farmer uses in the cultivation of Upland rice he realizes N1.75k.

\section{CONCLUSION AND RECOMMENDATIONS}

Rice production is a major source of livelihood for the resource poor farmers in Ebonyi State, Nigeria. The study has examined and determined the socio- economic factors that influence both Upland and Swamp rice output in the study area to include age, education, farming experience, farm size, variable inputs, capital inputs and farm income. The net profit of the farmers were also estimated indicating that Swamp rice farming was profitable than Upland rice farming in the study area.

Based on the findings the following recommendations were drawn:

- Reviewing the Land Use Act of 1990 is critical so that most of the fertile land held by government will be released to rice farmers. This will help boost rice production;

- Educational centres should be established by government in the rural areas, this will stimulate learning and adoption of improved rice technology packages by farmers;

- Subsidy and availability of farm inputs as improved rice seeds, fertilizers, herbicides among others by relevant agencies will increase rice production;

- Formation of farmer groups (cooperatives) is advocated so that farmers can pull their resources together to access credit and improved farm inputs in order to boost production;

- Rural facilities such as good roads, markets and agro based industries should be established by government. This will help curb rural- urban migration by the youths thereby help in providing skilled labour required in rice production and easy evacuation of farm produce. 


\section{REFERENCES}

[1] Anuebunwa F. O. (2007). Analysis of Seller Concentration and Market Performance in Rice Marketing Systems in Ebonyi State, Nigeria. Journal of Sustainable Tropical Agriculture Research 22 (1) 46-50.

[2] Anuebunwa, F. O. (2004). The Structure Conduct and Performance of the Marketing System for Garri in Abia State, Nigeria. Ph.D Thesis Federal University of Technology, Owerri, Imo State Nigeria.

[3] Audu, S.I (2008). Analysis of Cost and Return of Rice Production in Ankpa Local Government Area of Kogi State, Nigeria. Proceedings of the $42^{\text {nd }}$ Annual Conference of Agricultural Society of Nigeria Held at Ebonyi State University Abakaliki, Ebonyi State, Nigeria. October, 19- 23 Pp 768-771.

[4] Bonabana - Wabbi, J (2002). Assessing Factors Affecting Adoption of Agricultural Technologies. The Case of Integrated Pest Management (IPM) in Kumi District, Eastern Uganda. Msc Thesis Virgina Polytechnic Institute and State University USA.

[5] Ebonyi State Agricultural Development Programme (EBADEP) Abakaliki (2005). Annual Report.

[6] Ezeh, C.I (2006). Socio - Economic Determinants of Output and Profit Levels of Small Holder Rice Production Systems in Abia State, Nigeria. Journal of Research in Agriculture 3(3): $44-60$.

[7 ]Ezeh, C.I. and Nwachukwu, I.N. (2010). Micro Level Impact of National Fadama II Project on Rural Poverty in Imo State, Nigeria. African Journal of Food, Nutrition and Development 10(9):4016-4031.

[8] FAOSTAT (2004). Food and Agricultural Organization Statistics Division

[9] FAOSTAT (2007). Food and Agricultural Organization Statistics Division. http:faostat.fao.org/site/336/default.aspx.

[10] Food and Agricultural Organization (FAO) (2004). Concept Paper- The International Year of Rice, 2004.

[11] Food and Agricultural Organization (FAO) (2008). Regional Conference for Asia and the Pacific Beijing China, 17-21 May.

[12] Food and Agricultural Organization (FAO), (2004). Nigeria Rice Production, Increases and Import Duty Raised, www.fao.org.accessed30/12/07.

[13] Hirose, S and Wakatuski, T. (2002). Restoration of Inland Valley Ecosystem in West African Savannah, Norim Tokie,Kyota, Tokyo Japan Pp 60.

[14] Mbanasor, J.A and Obioha, I. O (2003). Resource Productivity Under Fadama Cropping System in Umuahia North Local Governmnet Area of Abia State. Journal of Tropical and Sub Tropical Agro ecosystems. 2(1): $81-86$.

[15] National Population Commission (NPC) (2006). Population Figures for Thirty Six States of Nigeria and Federal Capital Territory.

[16] Nwachukwu, I.N. Agwu, N.M and Ezeh, C.I. (2008). Comparative Study of Consumer Purchase Attitude of Local and Foreign Rice in Abia State. Proceedings of $42^{\text {nd }}$ of ASN held at EBSU, Abakaliki, October 19-23. Pp764-767.

[17] Nwaobiala C. U, Ekedo, T.O and Ezah, C.I. (2009). Socio - Economic Determinants of Home Gardeners in Ishiagu, Ivo LGA of Ebonyi State, Nigeria. International Journal of Agriculture, Food science and Eco system Research 1 (1): 188 - 192.

[18] Nwaobiala, C. U. (2013). Appraisal of Farmers' Participation in IFAD/FGN/NDDC/Community Based Natural Resource Management Programme in Abia and Cross River States Nigeria. A Ph.D Thesis Department of Agricultural Economics and Extension Abia State University Uturu.

[19] Nwaobiala, C.U. (2010). Effects of Green River Project on Cassava Farmers Production in Ogba/Egbema/Ndoni LGA of Rivers State, Nigeria. Global Approaches to Extension Practice (GAEP) Journal 6 (2): 18-23. 
[20] Nwaobiala, C.U. (2010). Economic Analysis of Swamp Rice Production in Ebonyi Southern Agricultural Zone of Ebonyi State, Nigeria. Journal of Agriculture and Social Research (JASR) 6 (2): 44-48.

[21] Onyenweaku, C.E., Okoye, B.C and Okorie, K. C (2010). Determinants of Fertilizer Adoption by Rice Farmers in Bende Local Government Area of Abia State, Nigeria. Nigerian Agricultural Journal 41 (2): $1-6$.

[22] Oyowole E, Ajayi, O. and Attah, E.S. (2010). Responses of Seven Upland Rice Cultivars to Three Sowing Methods in Ayigba, Kogi, State, Nigeria. Proceedings of 44th Annual Conference of ASN held at LAUTECH 18th-22nd October Pp. 116-119.

[23] Singh, B. N (1997). Breeding Objective for Low Land Rice Improvement in Africa. A Paper Presented at International Training Course on Low Land Rice Production and Management IITA Ibadan 16th April Pp 1-16.

[24] Ugwugwu C.S. (2008). Improved Rice Varieties. National Cereals Research Institute, Badeggi. A Paper Presented at Trainers Workshop on Rice Production held at Abia State Agricultural Development Programme 16-19th June.

[25] United States Agency for International Development (USAID) (2008). Improved Package Practices for Rice Production USAID MARKETS. Maximizing in Targeted Sites, Abuja Nigeria.

[26] West Africa Rice Development Association (WARDA) (2003). Strategy for Rice Sector Revitalization in Nigeria Project Report WARDA, Abidjan Cote d'Ivoire Pp 14.

[27] West African Rice Development Association (WARDA) (2003). Strategic Plan. 2001 2002. Buoake, Cote d'Ivorie.

[28] West African Rice Development Association (WARDA) (2002). News Letter. Buoake, Cote d'Ivorie.

[29] Umebali, E.E (2007). Principles of Agricultural Economics. Readings in Agricultural Economics and Extension. Akubuilo, C. J.C (ed) Computer Edge Publishers, Enugu Nigeria, Pp 19-36. 